\title{
Penerapan Model Pembelajaran Kooperatif Tipe Group To Group terhadap Peningkatan Hasil Belajar Siswa pada Mata Pelajaran PKn Kelas VII di MTs Al-Intishor Tanjung Karang Mataram
}

\author{
Zedi Muttaqien', Sri Mulyati² \\ ${ }^{1}$ Pendidikan Pancasila dan Kewarganegaraan, Universitas Muhammadiyah Mataram, Email: zedi.muttaqin@gmail.com \\ ${ }^{2}$ Pendidikan Pancasila dan Kewarganegaraan, Universitas Muhammadiyah Mataram, Email: mulyati_sri2@gmail.com
}

\begin{abstract}
INFO ARTIKEL
Riwayat Artikel:

Diterima: $\quad$ 13-

Februari-2019

Disetujui: 25-Maret2019
\end{abstract}

\section{Kata Kunci:}

penerapan group to group peningkatan hasil belajar

\begin{abstract}
ABSTRAK
Abstrak: Penggunaan metode ceramah yang begitu sering oleh guru PKn MTs. AL-Intishor khususnya guru kelas VII mengakibatkan sebagian besar siswa sering mengalami kesulitan memahami materi yang diajarkan. Tujuan penelitian untuk mengetahui bagaimana penerapan Model Pembelajaran Kooperatif Tipe Group To Group terhadap Peningkatan Hasil Belajar Siswa Pada Mata Pelajaran PKn Kelas VII MTs. Al-Intishor Tanjung Karang. Metode penelitian menggunakan penelitian tindakan kelas dengan 3 siklus yang memuat tahap perencanaan, pelaksanaan, observasi, dan refleksi. Subjek penelitian adalah siswa kelas VII MTs. Al-Intishor yang berjumlah 21 siswa. Pendekatan yang digunakan adalah pendekatan kualitatif dan pendekatan kuantitatif. Metode pengumpulan data menggunakan tes hasil belajar, dan lembar observasi. Data yang diperoleh berupa hasil tes yaitu berupa tes siklus I (SI), tes siklus II (SII), tes siklus III (SIII) serta lembar observasi siswa dalam kegiatan belajar mengajar. Hasil penelitian menunjukkan adanya peningkatan rata-rata hasil belajar siswa yaitu pada siklus I 46,4 dengan persentase ketuntasan 76,19\%. Pada siklus II rata-rata hasil belajar siswa adalah 50,6 dengan persentase ketuntasan $100 \%$ kemudian pada siklus III ratarata hasil belajar siswa adalah 51,13 dengan persentase ketuntasan $100 \%$, sehingga dapat disimpulkan bahwa Penerapan Model Pembelajaran Kooperatif Tipe Group To Group dapat meningkatkan hasil belajar siswa pada mata pelajaran PKn kelas VII MTs. Al-Intishor.
\end{abstract}

\begin{abstract}
The use of a lecture method that is so frequent by the teacher of PKn MTs. ALIntishor especially the teacher of class VII resulted in most students often having difficulty understanding the material being taught. The research aims to determine how the implementation of cooperative learning Model type Group To Group towards the improvement of student learning outcomes on PKn class VII. Al-Intishor Tanjung Karang. The research method uses class action research with 3 cycles that contain planning, implementation, observation, and reflection stages. The subject of the study is a student of class VII MTs. Al-Intishor, numbering 21 students. The approach used is a qualitative approach and a quantitative approach. Data collection methods using study results tests, and observation sheets. The Data obtained in the form of a test result is tested cycle I (SI), Cycle test II (SII), Cycle III test (SIII) as well as student observation sheet in teaching learning activities. The results showed that there was an increase in the average student learning outcome at the / 46.4 cycle with a percentage of $76.19 \%$. On the average cycle of student learning outcomes is 50.6 with a percentage of $100 \%$ at the end of the III percent of student learning outcomes is 51.13 with a percentage of the compensation of 100\%, so it can be concluded that the learning Model implementation Cooperative type Group To Group can improve student learning outcomes in the subjects of PKn-class VII MTs. Al-Intishor.
\end{abstract}

\section{A. LATAR BELAKANG}

Tujuan pendidikan nasional adalah untuk meningkatkan kualitas manusia Indonesia yang beriman dan bertakwa terhadap Tuhan Yang Maha Esa, berbudi pekerti luhur, berkepribadian, ber-disiplin, bekerja keras, tangguh, bertanggung jawab, mandiri, cerdas, dan terampil serta sehat jasmani dan rohani [1]. Sejalan dengan itu untuk mencapai tujuan pendidikan nasional membutuh-kan usaha dan kerja keras yang terus menerus dan berkesinambungan serta melibatkan banyak faktor pendukung yaitu faktor internal dan eksternal.
Salah satu masalah pendidikan yang kita hadapi dewasa ini adalah rendahnya mutu pendidikan pada setiap jenjang dan satuan pendidikan khususnya pendidikan dasar dan menengah. Berbagai usaha telah dilakukan, antara lain memlalui berbagai pelatihan dan peningkatan kualifikasi guru, penyediaan dan perbaikan sarana/prasarana pendidikan, serta peningkatan mutu manajemen sekolah [2]. Peningkatan mutu pendidikan merupakan prioritas utama dalam penyelenggaraan pendidikan. Pemerintah melalui Departemen Pendidikan Nasional telah berupaya untuk meningkatkan mutu pendidikan melalui penyelenggaraan pendidikan yang 
berkualitas seperti pelatihan dan peningkatan kualifikasi guru, penyempurnaan kurikulum dan penyediaan sarana dan prasarana pendidikan dengan harapan tujuan dari proses belajar mengajar mudah tercapai dan siswa dengan mudah memahami semua konsep yang diterima.

Namun demikian realitas dilapangan menunjukan belum tercapainya tujuan yang dimaksud berdasarkan refleksi awal di MTs. Al-Intishor Tanjung Karang Mataram terkuat kondisi belajar dan pembelajaran PKn antara lain diketahui bahwa siswa cenderung kurang aktif dan hanya menerima maupun mencatat hal-hal atau materi yang disampaikan oleh guru, tanpa berusaha mencarinya. Karena siswa yang kurang aktif tersebut terkadang guru sulit membedakan apakah siswa sudah mengerti atau tidak tentang materi yang sudah disampaikan, masalah tersebut harus dipecahkan bersama untuk mendukung terselenggranya pendidikan yang bertujuan untuk mencerdaskan bangsa.

Pada proses pembelajaran Pendidikan kewarganegaraan, kebanyakan guru lebih mendominasi proses pembelajaran dengan metode ceramah yang diikuti oleh contoh soal, sedangkan siswa hanya duduk mendengar, mencatat, menghafal dan bekerja. Peranan guru lebih dominan dan motivasi siswa masih kurang. Sehingga partisipasi siswa untuk mengemukakan konsep dan menemukan sendiri pemecahan dari suatu masalah masih kurang. Hal ini akan berdampak pada rendahnya mutu pendidikan yang salah satunya ditunjukkan oleh rendahnya prestasi belajar yang dicapai siswa.

Untuk meningkatkan prestasi belajar khususnya untuk memacu penguasaan materi pelajaran dijenjang SMP/MTs perlu adanya penyempurnaan proses belajar mengajar termasuk dalam pelajaran pendidikan kewarganagaraan agar diperoleh hasil yang lebih baik. Keberhasilan pelajaran dalam arti tercapainya tujuan instru-ksional sangat tergantung pada kemampuan guru dalam mengelola proses belajar. Guru sebagai salah satu komponen yang menentukan suksesnya kegiatan pembelajaran dituntut untuk dapat memilih dan menggunakan metode-metode atau teknik-teknik mengajar yang tepat dalam materi pelajaran.

Pada proses pembelajaran banyak tantangan yang sering dihadapi oleh guru dalam suatu pembelajaran. Adapun tantangan yang dimaksud adalah.

a. Bagaimana menemukan cara yang terbaik untuk menyampaikan berbagai konsep yang diajarkan di dalam mata pelajaran tertentu, sehingga siswa dapat menggunakan dan mengingat lebih lama konsep-konsep tersebut.

b. Bagaimana setiap mata pelajaran dipahami sebagai bagian yang saling berhubungan dan membentuk satu persamaan yang utuh.

c. Bagaimana seorang guru dapat berkomu-nikasi secara efektif dengan siswanya yang selalu bertanya-tanya tentang alasan dari sesuatu, arti dari sesuatu dan hubungan dari apa yang mereka pelajari. d. Bagaimana guru dapat membuka wawasan berpikir yang beragam dari seluruh siswa, sehingga mereka dapat mempelajari berbagai konsep dan cara mengaitkannya dengan kehidupan nyata, sehingga dapat membuka berbagai pintu kesempatan selama hidupnya [2].

Berdasarkan hasil wawancara awal bahwa guru bidang studi yang mengajar dikelas VII, rata-rata nilai PKn pada semester I adalah 6,0 yang menunjukan nilai rata-rata yang belum tuntas yang mana nilai ketuntasan dengan nilai rata-rata 6,5. Hal ini masih rendah dibandingkan dengan ketuntasa klasikal yang dituntut kurikulum 1994 yaitu 85\% dari jumlah siswa dapat mencapai 6,5 minimal yang menjadi standar ketuntasan belajar siswa keadaan ini menunjukan bahwa siswa belum optimal.

Untuk mengatasi persoalan tersebut di atas, diperlukan suatu metode pembelajaran dengan melakukan tindakan yang dapat melibatkan siswa untuk lebih aktif dalam kegiatan belajar mengajar dan konstruksi pengetahuan yang perlu mereka kuasai sehingga terjadi proses pembelajaran yang bermakna. Salah satu alternatif yang ditawarkan peneliti adalah dengan penerapan pembelajaran kooperatif tipe group to group.

Belajar mengajar adalah suatu kegiatan yang bernilai edukatif. Nilai edukatif mewarnai interaksi yang terjadi antara guru dengan siswa. Ini dikarenakan kegiatan belajar mengajar yang dilakukan tersebut diarahkan untuk mencapai tujuan tertentu yang telah dirumuskan sebelum pengajaran dilakukan. Harapan yang tidak pernah sirna dan selalu dituntut oleh guru adalah bagaimana bahan pelajaran yang telah disampaikan guru dapat dikuasai oleh siswa secara tuntas.Ini merupakan masalah yang cukup sulit yang dirasakan oleh guru. Kesulitan itu dikarenakan siswa bukan hanya sebagai individu dengan segala keunikannya, tetapi mereka juga sebagai makhluk sosial dengan latar belakang yang berbeda.Paling tidak ada tiga aspek yang membedakan antara siswa yang satu dengan yang lainnya yaitu aspek intelektual, psikologis dan biologis.

Sebagai seorang pendidik, guru harus berperan aktif, serta memiliki wawasan yang mantap dan luas dalam kegiatan belajar mengajar. Salah satu wawasan yang harus dimiliki oleh guru adalah strategi belajar mengajar. Sehubungan dengan itu guru harus kreatif, profesional dan menyenangkan. Sebagai pendidik, guru harus memahami setiap individu siswa, dan juga harus memiliki kepekaan, karena guru berperan sebagai fasilitator yang menyediakan suasana belajar yang menyenangkan, yang dengannya memungkinkan siswa berhasil mengembangkan potensinya menjadi lebih besar. Di samping itu juga, guru harus pandai menggunakan pendekatan secara aktif dan bijaksana. Untuk itu sebaiknya guru mengenal siswa sebagai individu dengan segala perbedaannya, antara siswa yang 
satu dengan yang lainnya. Oleh karena itu, ada berbagai model atau strategi dalam kegiatan belajar mengajar yang perlu diperhatikan dengan harapan dapat membantu siswa memperoleh pemahaman yang baik terkait dengan materi yang diajarkan.

Berdasarkan permasalahan tersebut, maka perlu adanya upaya guru untuk meningkatkan hasil belajar siswa dengan memfariasikan metode ceramah dengan model pembelajaran berbasis masalah, pembelajaran mengatasi permasalahan siswa tersebut yaitu dengan menerapkan metode pembelajaran kooperatif tipe group to group. Tipe group to group merupakan. "Pembelajaran group to group atau disebut model pembelajaran pertukaran kelompok mengajar ini, tugas yang berbeda diberikan kepada kelompok peserta didik yang berbeda. Masing-masing kelompok "mengajar" apa yang telah dipelajari untuk sisa kelas" [3].

Berdasarkan uraian latar belakang tersebut, maka peneliti memandang perlu diadakan Penelitian Tindakan Kelas (PTK) dengan judul "Penerapan Model Pembelajaran Kooperatif Tipe Group To Group Terhadap Peningkatan Hasil Belajar Siswa Pada Mata Pelajaran PKn Kelas VII MTs. Al- Intishor Tanjung Karang Mataram. penelitian ini bertujuan untuk mengetahui apakaj penerapan Penerapan Model Pembelajaran Kooperatif Tipe Group To Group dapat meningkatkan hasil belajar siswa pada mata pelajaran Pendidikan Kewarganegaraan kelas VII di MTs. AlIntishor Tanjung Karang Mataram.

\section{B. METODE PENELITIAN}

\section{Metode Penelitian yang Digunakan}

Adapun jenis penelitian yang digunakan adalah Penelitian Tindakan Kelas (PTK). Penelitian tindakan kelas adalah penelitian yang dilakukan oleh guru, peneliti di dalam kelas, dengan tujuan untuk memperbaiki kinerja guru sehingga hasil belajar siswa menjadi meningkat”. Penelitian tindakan kelas (Classroom Action Research) merupakan suatu pencermatan terhadap kegiatan belajar berupa sebuah tindakan, yang sengaja dimunculkan dan terjadi dalam sebuah kelas secara bersama [4].

Berdasarkan pendapat di atas, maka penelitian tindakan kelas adalah penelitian yang dilakukan oleh guru dalam kelasnya sendiri melalui refleksi diri, dengan tujuan memperbaiki kinerjanya sebagai guru, sehingga hasil belajar siswa menjadi lebih meningkat.

\section{Metode Pengumpulan Data}

Metode pengumpulan data adalah tehnik atau caracara yang dapat digunakan oleh peneliti untuk mengumpulkan data. Metode menunjukan sesuatu kata yang abstrak dan tidak diwujudkan dalam suatu benda, tetapi hanya dilihat penggunaa melalui: wawancara, pengamatan, ujian (tes), dokumentasi dan lainnya [5].

Berdasarkan pendapat diatas maka dapat disimpulkan dengan metode sebagai berikut:

\section{a. Metode Tes}

Tes adalah sebuah instrumrn pengumpulan data dalam penelitian untuk mengukur penge-tahuan, pengalaman, dan keterampilan responden" [6]. Pendapat lain menyatakan bahwa "Tes merupakan serangkaian pertanyaan yang diberikkan kepada seseorang atau kelompok, dengan maksud untuk mengukur kemampuan sesuai dengan bidang yang dites" [7].

Dari berbagai pendapat di atas maka dapat disimpulkan bahwa metode tes adalah suatu cara mendapatkan data dengan menyebarkan tes kepada responden. Dalam penelitian ini menggunakan tes yang berkaitan dengan penerapan model pembelajaran kooperatif tipe group to group terhadap peningkatan hasil belajar siswa pada mata pelajaran pkn kelas VII di MTs. Al-Intishor Tanjung Karang Mataram. Adapun jumlah seluruh angket dalam penelitian ini berjumlah 24 orang.

\section{b. Dokumentasi}

Metode dokumentasi adalah mencari data mengenai hal-hal atau variabel yang diperlukan penulis tentang daerah geografis lokasi penelitian, struktur pengurus, program kerja dan lain sebagainya. Untuk mendapatkan data tertulis seperti diatas, penulis datang langsung kelokasi penelitian.

Pendapat para ahli menyatakan, "Metode dokumentasi adalah mencari sesuatu data mengenai hal-hal atau variabel yang berupa catatan, transkrip, buku, surat kabar, majala, prasasti, notulen rapat, agenda dan lain sebagainya" [8]. Pendapat lain menyatakan metode "Documenter adalah metode pengumpulan data dengan memanfaatkan dokumen yang meliputi laporan yang tertulis dari suatu peristiwa seperti catatan hasil rapat, keputusan laporan panitia kerja dan lain-lain" [9].

Adapun data yang dikumpulkan melalui matode dokumentasi adalah data tentang gambaran umum lokasi penelitian.

\section{Jenis dan Sumber Data}

\section{a) Jenis Data}

Adapun Jenis data dalam penelitian dapat digolongkan menjadi dua bagian pokok yakni data kualitatif dan data kuantitatif, untuk mengklasifikasikan pendapat para ahli dibawa ini.

Data menurut jenisnya ada dua yaitu data kualitatif dan data kuantitatif.

1) Data Kualitatif

Data kualitatif yaitu data yang berhubungan dengan kategorisasi, karakteristik berwujud pertanyaan atau berupa kata-kata, misalnya wanita itu cantik, pria itu tanpan, baik, buruk dan lain-lain

2) Data Kuantitatif

Data kuantitatif yaitu data yang berupa angkaangka [5]. Data kuantitafif dibedakan menjadi 4 macam yait. 
a. Skala normatif merupakan skala penguku-ran yang menggambarkan perbedaan berbagai hal berdasarkan pada kategori-kategori, tidak menunjukan adanya kreteria urutan tinggi rendah dalam kedudukan;

b. Skala ordinal, merupakan skala yang menyatakan perbedaan jumlah dan tingkatnya. Bias pula merupakan urutan kedudukan klasifikasi yang bias dinyatakan "lebih besar dari pada atau lebih kecil dari pada";

c. Skala interval, merupakan suatu skala yang didasarkan pada unit-unit pengukuranyang sama, menunjukan besar kecilnya suatu sifat atau karateristik tertentu;

d. Skala rasio, sebenarnya skala ini memiliki interval yang sama dengan skala interval namun masih ada ciri lainya yaitu bahwa, skala rasio memiliki harga nol mutlak.

Berdasarkan jenis data yang dipergunakan dalam penelitian ini adalah data kuantitatif yang berskala interval.

\section{b) Sumber Data}

Ditinjau dari sifatnya sumber data terdiri dari.

a. Data Primer adalah sumber-sumber yang memberikan data langsung dari tangan pertama.

b. Data Sekunder adalah data atau keterangan yang dikutif dari sumber lain [9].

Berdasarkan pendapat diatas yang menjadi data primer dalam penelitian ini adalah data hasil observasi, dan hasil tes. Sedangkan data sekunder dalam penelitian ini adalah data hasil-hasil dokumentasi.

\section{Identifikasi dan Operasional Variabel}

\section{a. Identifikasi Variabel}

Untuk tidak menimbulkan kerancauan, terlebih dahulu dipahami makna variable itu sendiri, dimana variable di artikan sebagai "konsep yang mempunyai variasi atau variable adalah pengelompokan yang logis dari dua atributatau lebih" [10].

Dalam penelitian variable dikelompokan menjadi dua yaitu.

a. Variabel bebas yaitu variabel yang mempengaruhi variabel terikat.

b. Variabel terikat yaitu variabel yang dipengaruhi oleh variabel bebas [11].

Dari pendapat diatas, dapat diambil kesimpulan bahwa variabel bebas dalam penelitian ini adalah metode "kooperatif tipe group to group". Sedangkan, variabel terikatnya adalah peningkatan hasil belajar siswa kelas VII di MTs Al-Intishor Tanjung Karang Mataram.

\section{b. Definisi Operasional Variabel}

Devinisi operasional variabel adalah suatu definisi yang diberikan kepada suatu veriabel dengan cara memberikan arti atau memberikan operasianal yang diperlikan untuk mengukur variabel tersebut [12]. a. Pembelajaran kooperatif tipe group to group merupakan strategi pembelajaran yang mengutamakan adanya kerja sama antara siswa dalam kelompok untuk mencapai tujuan pembelajaran pembelajaran pertukaran kelompok mengajar ini, tugas yang berbeda diberikan kepada kelompok peserta didik yang berbeda. Masingmasing kelompok "mengajar" apa yang telah dipelajari untuk sisa kelas.

b. Hasil belajar adalah suatu usaha yang berlangsung di dalam diri seseorang yang mengubah tingkah laku dalam afektif, psikomotorik, kognitif.

\section{Tahapan Penelitian}

Penelitian ini adalah penelitian tindakan kelas (PTK). Penelitian tindakan kelas ini dilaksanakan dalam bentuk siklus. Setiap siklus terdiri dari empat tahap kegiatan yaitu: tahap perencanaan, tahap pelaksanan, tahap observasi dan evaluasi dan tahap refleksiyang setiap siklus terdiri dari satu kali pertemuan dengan gambar bagan sebagai berikut [8]:

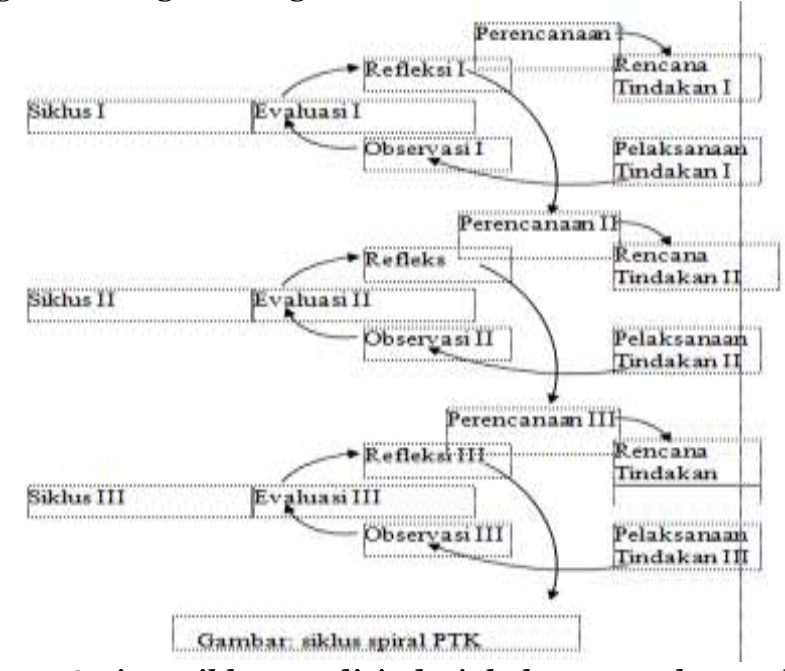

Setiap siklus terdiri dari beberapa tahap sebagaI berikut.

\section{Siklus I}

\section{1) Tahap Perencanaan}

Pada tahap ini, hal-hal yang dilakukan oleh peneliti adalah:

a. menerapkan metode pembelajaran yang digunakan;

b. menyiapkan rencana pelaksanaan pembela-jaran (RPP);

c. mempersiapkan dan menyusun lembar observasi untuk mencatat aktifitas siswa selama pembelajaran berlangsung;

d. menyiapkan lembar kerja siswa (LKS);

e. menyusun dan menyiapakan soal tes hasil belajar dalam bentuk pilihan ganda dan essay.

\section{2) Tahap Pelaksanaan}

Langkah-langkah tindakan adalah topik yang perlu didiskusikan dalam perencanaan umum, misalnya bagaimana proses implementasi inovasi akan 
dilakukan beserta dukungan median dan bentuk evaluasi yang diperlukan, hasil yang diharapkan, bagaimana proses monitoring untuk membuktikan hasil inovasi yang dilakukan, juga tehnik-tehnik yang memungkinkan seseorang melihat apa yang sedang terjadi dari beberapa sudut pandang [13].

Yang digunakan pada tahap pelaksanaan ini yaitu melaksanakan kegiatan mengajar di kelas sesuai dengan rencana yang telah dituangkan dalam scenario pembelajaran dengan model pembelajaran kooperatif tipe group to group.

\section{3) Tahap Observasi}

Biasanya dalam melakukan observasi, kita cenderung melakukan penilaian atau menafsirkan, atau memberikan vonis terlalu cepat. Selama pelaksanaan tindakan observasi, yang akan diamati adalah kegiatan guru dan aktifitas siswa yang nampak selama proses pembelajaran berlangsung sesuai dengan skenario yang telah dibuat. Semua aktifitas siswa yang Nampak dicatat dalam lember observasi yang telah disiapkan pada akhir siklus penguasaan siswa terhadap konsep-konsep yang dipelajari secara individu.

Manfaat observasi dalam penelitian akan terwujud apabila dilakukan dengan cermat, yaitu:

a) Dilakukan dalam waktu 24 jam sesudah kegiatan tindakan dilakukan.

b) Berdasarkan catatan lapangan yang ditulis dengan sistematis dan cermat.

c) Berdasarkan data factual.

d) Data factual ditafsirkan berdasarkan criteria yang telah disetujui.

e) Penafsiran diberikan pertama kali oleh guru yang diobservasi.

f) Untuk selanjutnya dirundingkan bersama mitra penelitian lainnya dalam diskusi dua arah.

g) Menghasilkan strategi selanjutnya dalam siklus berikutnya [13].

\section{4) Tahap Refleksi}

Pada tahap ini peneliti sebagai observer, mengkaji kekurangan dari tindakan yang diberikan pada tiap siklus. Hal ini dilakukan dengan caramelihat data hasil observasi dan evaluasi. Jika refleksi siklus I hasil yang diperoleh belum optimal, maka pada siklus berikutnya perlu diadakan perbaikan atau penyempurnaan perencanaan dan pelaksanaan pada siklus selanjutnya.

\section{Siklus II}

Pada siklus II sama dengan siklus I tetapi siklus II akan diadaka revisi atau perbaikan-perbaikan berdasarkan hasil refleksi siklus I.

\section{Siklus III}

Pada siklus III sama dengan siklus II tetapi siklus III akan diadakan revisi atau perbaikan-perbaikan berdasarkan hasil refleksi siklus II.

\section{Metode Analisis Data}

Analisis data adalah proses memindahkan data kedalam peta, kategori dan satuan uraian sehingga dapat ditentukan tema dan dapat dirumuskan hipotesis kerja seperti yang disarankan oleh data [14].

a. Data hasil observasi

Data hasil observasi dianalisis dengan langkahlangkah sebagai berikut:

1) Menganalisa data dan mendeskripsikan hasil observasi pembelajaran untuk setiap siklus dengan menerapkan pembelajaran kooperative tipe group to group dalam meningkatkan hasil belajar ;

2) Menganalisa data dan mendiskripsikan langkahlangkah guru dalam menerapkan pembelajaran kooperative tipe group to group dalam meningkatkan hasil belajar

b. Data Tes Hasil Belajar

Setelah memperoleh data hasil belajar, maka data tersebut dianalisis dengan mencari ketuntasan belajar, kemudian dianalisis secara kuantitatif.

1) Ketuntasan Individu.

Setiap siswa dalam proses belajar mengajar dikatakan tutas apabila memperoleh nilai lebih atau sama dengan 6,5 [15]

\section{2) Ketutasan Klasikal}

Untuk mencari prosentase prestasi belajar setelah proses pembelajaran segitiga dengan pembelajaran kooperatif group to group digunakan rumus prosentase adalah sebagai berikut [16]:

$$
\begin{array}{lc}
P=\frac{R}{T} & x 100 \% \\
\mathrm{P} & =\text { Prosentase ketuntasan klasikal } \\
\mathrm{R} & =\text { Jumlah siswa yang mendapat nilai } \\
& \text { lebih besar sama dengan } 6,5 \\
\mathrm{~T} & =\text { Jumlah siswa }
\end{array}
$$

Patokan untuk menyatakan ketuntasan klasikal dalam proses pembelajaran segitiga dengan pembelajaran kooperatif group to group adalah minimal $85 \%$ yang nilainya $\geq 65$.

\section{HASIL DAN PEMBAHASAN}

\section{a) Siklus I}

1) Tahap Perencanaan

Pada tahap ini dilakukan beberapa perencanaan sebelum dilakukan proses belajar) mengajar. Pada tahap perencanaan untuk siklus I adalah sebagai berikut:

a. Menyiapkan bahan ajar;

b. Menyiapkan perencanaan pembelajaran (RPP) yang dikembangkan berdasarkan pendekatan metode kooperatif tipe group to group;

c. Menyiapkan soal tes beserta jawaban untuk mengetahui hasil belajar siswa.

2) Tahap Pelaksanaan

Dalam tahap pelaksanaan ini yang dilakukan oleh peneliti adalah melaksanakan pembelajarn sesuai dengan rencana pembelajaran yang telah 
disusun dan dirancang berdasarkan pendekatan penerapan metode pembelajaran kooperatif tipe group to group. Pada tahap pelaksanaan siklus I adalah sebagai berikut:

Dilaksanakan pertemuan pertama pada tanggal 10 Oktober, dikelas VII dengan waktu yang tersedia 2 X 40 menit. Menyampaikan meteri yang materi yang menyangkut. Kemudian dilanjutkan dengan diskusi kelompok berdasarkan pendekatan penerapan pembelajaran kooperatif tipe group to group.

Proses pembelajaran guru dan kegiatan siswa. Kegiatan guru mencakup beberapa kegiatan yakni guru melaksanakan kegiatan pembelajran dengan tepat waktu, melaksanakan langkah-langkah pembelajaran sesuai dengan alokasi waktu, belajar yang direncanakan, menguasai kelas, menyampaikan kegiatan pembelajaran memungkinkan tumbuhnya kegiatan positif, dengan menggunakan metode pembelajaran kooperatif tipe group to group, memberikan petunjuk atau penjelasan yang berkaitan dengan model dan metode pembelajaran, materi pembelajaran, memberikan kesempatan pada siswa untuk terlibat secara langsung dalam pembelajaran dan memberikan motivasi atau penghargaan. Kegiatan siswa mencakup aktifitas bertanya, aktif mengeluarkan pendapat atau ide, antusias dalam menyampaikan pendapatnya, memberikan pendapat dan menyimpulkan materi pelajaran.

3) Tahap Evaluasi

a. Hasil Test Siklus I

Tabel 4

Hasil test siklus I

\begin{tabular}{lllll}
\hline No & Nama Siswa & L/P & Nilai & $\begin{array}{l}\text { K } \\
\text { et }\end{array}$ \\
\hline 1 & Akidah & P & 69 \\
2 & Ari Pathurrahman & L & 66 \\
3 & Azan Aswadi & L & 66 \\
4 & Badrul Islam & L & 66 \\
5 & Fatin Adensa & Cahya & P & 69 \\
6 & Sasmita & & \\
7 & Hairul Mizam & L & 69 \\
8 & Haril Lutfi & L & 66 \\
9 & Hudzamma & P & 69 \\
10 & Hurniati & P & 63 \\
11 & Huswatun Hasnah & P & 60 \\
12 & Ilham Aji Pagestu & P & 66 \\
13 & Ilham Farizi & L & 60 \\
14 & Nurul Hidayah & P & 63 \\
15 & Sahdi & L & 66 \\
16 & Sahrul Rozi & L & 60 \\
17 & Samratul Janiah & P & 72 \\
18 & Suhaebatul Islamiyah & P & 69 \\
19 & Silvianingsih & P & 72 \\
20 & Suriani & P & 69 \\
21 & Susilawati & P & 66 \\
\hline Jumlah & & 1392 \\
Rata-rata & & 46,4 \\
\hline \multicolumn{7}{l}{} & & & \\
\hline
\end{tabular}

\begin{tabular}{ll}
\hline Presentase & 76,19 \\
\hline
\end{tabular}

Keterengan:

1. Banyaknya siswa tuntas belajar : 16 orang

2. Banyaknya siswa yang tidak tuntas belajar: 5 orang

3. Presentase siswa yang tuntas belajar: $\quad 76,19$

$$
\begin{aligned}
\text { Ketuntasan Belajar Klasikal } & =\frac{\text { Jumlah Siswa yang Tuntas }}{\text { Jumlah Siswa }} \times 100 \\
& =\frac{16}{21}
\end{aligned}
$$

Siswa yang tuntas belajar 16 orang atau sebanyak 76,19\%.

4) Tahap Refleksi

Berdasarkan hasil penelitian siklus I yaitu hasil evaluasi kegiatan pembelajaran maka perlu dilakukan perbaikan-perbaikan pada siklus II. Adapun rencana perbaikan yang dilakukan pada siklus II adalah:

a. Siswa kurang berani bertanya kepada guru maupun kepada temannya ketika masih belum mengerti. Hal ini disebabkan karena siswa masih malu dan ditertawakan oleh temannya. Untuk mengatasi hal tersebut guru memberikan point tambahan kepada siswa yang berani bertanya maupun mengeluarkan pendapat.

b. Pada saat diskusi siswa kurang bias menjawab pertanyaan temannya. Hal tersebut disebabkan siswa kurang siap dalam menjawab pertanyaan yang diajukan temannya. Untuk mengatasi hal tersebut guru memberikan motivasi kepada sisswa untuk belajar dan mengusahakan menjawab pertanyaan yang diajukan oleh temannya.

c. Siswa kurang memperhatikan dan menghargai penjelasan dari temannya. Hal tersebut diatasi dengan mengarahkan dan menyuru siswa yang lain untuk menjelasakan penjelasan temannya.

d. Siswa kurang dalam menyimpulkan materi yang telah dipelajari. Untuk mengatasinya guru harus lebih efektif lagi dalam menarik kesimpulan.

\section{b) Siklus II}

Pada siklus II sama dengan siklus I mulai dari Tahap Perencanaan dan Tahap Pelaksanaannya tetapi siklus II akan diadakan perbaikanperbaikan berdasarkan hasil refleksi siklus I.

a) Tahap Evaluasi

a. Hasil Test

Tabel 5

Hasil Test Siklus II

\begin{tabular}{llcll}
\hline No & Nama Siswa & L/P & Nilai & $\begin{array}{l}\text { K } \\
\text { et }\end{array}$ \\
\hline
\end{tabular}




\begin{tabular}{llll}
\hline 1 & Akidah & P & 75 \\
2 & Ari Pathurrahman & L & 72 \\
3 & Azan Aswadi & L & 72 \\
4 & Badrul Islam & L & 72 \\
5 & Fatin Adensa & P & 75 \\
& cahya Sasmita & & \\
6 & Hairul Mizam & L & 75 \\
7 & Haril Lutfi & L & 72 \\
8 & Hernil & P & 75 \\
9 & Hudzamma & P & 69 \\
10 & Hurniati & P & 66 \\
11 & Huswatun Hasnah & P & 72 \\
12 & Ilham Aji Pagestu & L & 66 \\
13 & Ilham Farizi & L & 69 \\
14 & Nurul Hidayah & P & 72 \\
15 & Sahdi & L & 72 \\
16 & Sahrul Rozi & L & 66 \\
17 & Samratul Janiah & P & 78 \\
18 & Suhaebatul & P & 75 \\
& Islamiyah & & \\
19 & Silvianingsih & P & 78 \\
20 & Suriani & P & 75 \\
21 & Susilawati & P & 72 \\
\hline Jumlah & & 1520 \\
Rata-rata & & 50,6 \\
Presentase & & 100 \\
Keterengan: & & \\
\hline
\end{tabular}

Keterengan:

1. Banyaknya siswa tuntas belajar : 21 orang

2. Banyaknya siswa yang tidak tuntas belajar o orang

3. Presentase siswa yang tuntas belajar: 100

$$
\begin{aligned}
\text { Ketuntasan Belajar Klasikal } & =\frac{\text { Jumlah Siswa yang Tuntas }}{\text { Jumlah Siswa }} \times 100 \\
& =\frac{16}{21} \\
& =100
\end{aligned}
$$

Siswa yang tuntas belajar 21 orang atau sebanyak $100 \%$.

b) Tahap Refleksi

Walaupun pada silkus II menunjukan hasil evaluasi yang cukup memuaskan tetapi masih belum tuntas maka dari itu diadakan perbaikan pada siklus III.

a. Guru harus lebih menekankan kepada siswa agar bersdiskusi dan saling bekerjasama dalam kelompok.

b. Guru memotivasi siswa untuk lebih berani mengemukakan pendapatnya, jangan takut salah dan jika siswa mengalami kesulitan jangan malu bertanya kepada teman dalam kelompok maupun guru.

c. Antusiasme siswa untuk berdidkusi kelompok juga harus ditingkatkan.

d. Guru harus lebih mempersiapkan diri dalam mengajar agar dapat menguasai kelas dengan baik.

e. Guru harus dapat membimbing siswa dengan baik dalam membuat kesimpulan. f. Guru harus lebih memotivasi siswa dalam belajar dengan menyampaikan manfaat dari materi yang mereka pelajari.

Guru lebih intensif membimbing siswa yang nilainya $<65$.

\section{c) Siklus III}

Pada siklus IIIsama dengan siklus II mulai dari Tahap Perencanaan dan Tahap Pelaksanaannya tetapi siklus III akan diadakan perbaikanperbaikan berdasarkan hasil refleksi siklus II.

5) Tahap Evaluasi

a) Hasil Test

Tabel 6

Hasil Test Siklus III

\begin{tabular}{lllll}
\hline No & Nama Siswa & L/P & Nilai & $\begin{array}{l}\text { K } \\
\text { et }\end{array}$ \\
\hline 1 & Akidah & P & 81 \\
2 & Ari Pathurrahman & L & 78 \\
3 & Azan Aswadi & L & 78 \\
& & & \\
4 & Badrul Islam & L & 78 \\
5 & Fatin Adensa & P & 81 \\
& cahya Sasmita & & \\
6 & Hairul Mizam & L & 81 \\
7 & Haril Lutfi & L & 78 \\
8 & Hernil & P & 81 \\
9 & Hudzamma & P & 75 \\
10 & Hurniati & P & 72 \\
11 & Huswatun Hasnah & P & 78 \\
12 & Ilham Aji Pagestu & L & 72 \\
13 & Ilham Farizi & L & 75 \\
14 & Nurul Hidayah & P & 78 \\
15 & Sahdi & L & 78 \\
16 & Sahrul Rozi & L & 72 \\
17 & Samratul Janiah & P & 84 \\
18 & Suhaebatul & P & 81 \\
& Islamiyah & & \\
19 & Silvianingsih & P & 84 \\
20 & Suriani & P & 81 \\
21 & Susilawati & P & 78 \\
\hline Jumlah & & 1534 \\
Pata-rata & & 51,13 \\
\hline Kesentase & & 100 \\
\hline
\end{tabular}

Keterengan:

1. Banyaknya siswa tuntas belajar : 21 orang

2. Banyaknya siswa yang tidak tuntas belajar o orang

3. Presentase siswa yang tuntas belajar: 100

$$
\begin{aligned}
\text { Ketuntasan Belajar Klasikal } & =\frac{\text { Jumlah Siswa yang Tuntas }}{\text { Jumlah Siswa }} \times 100 \\
& =\frac{16}{21}
\end{aligned}
$$

Siswa yang tuntas belajar 21 orang atau sebanyak $100 \%$.

Tabel o6

Perbandingan siklus I, sikls II, dan siklus III Halis test siklus III 


\begin{tabular}{lccc}
\hline Aspek yang Diukur & \multicolumn{3}{c}{ Perbandingan Siklus I, II, dan III } \\
& Siklus I & Siklus II & Siklus III \\
\hline $\begin{array}{l}\text { Siswa yang tuntas } \\
\begin{array}{l}\text { Rata-rata hasil } \\
\text { belajar }\end{array}\end{array}$ & $\mathbf{1 6}$ & $\mathbf{2 1}$ & $\mathbf{2 1}$ \\
\hline Ketuntasan & 76,4 & 50,6 & 51,13 \\
\hline
\end{tabular}

Dapat dijabarkan dalam bentuk grafik. Grafik 1

Grafik SiklusI, Siklus II dan Siklus III
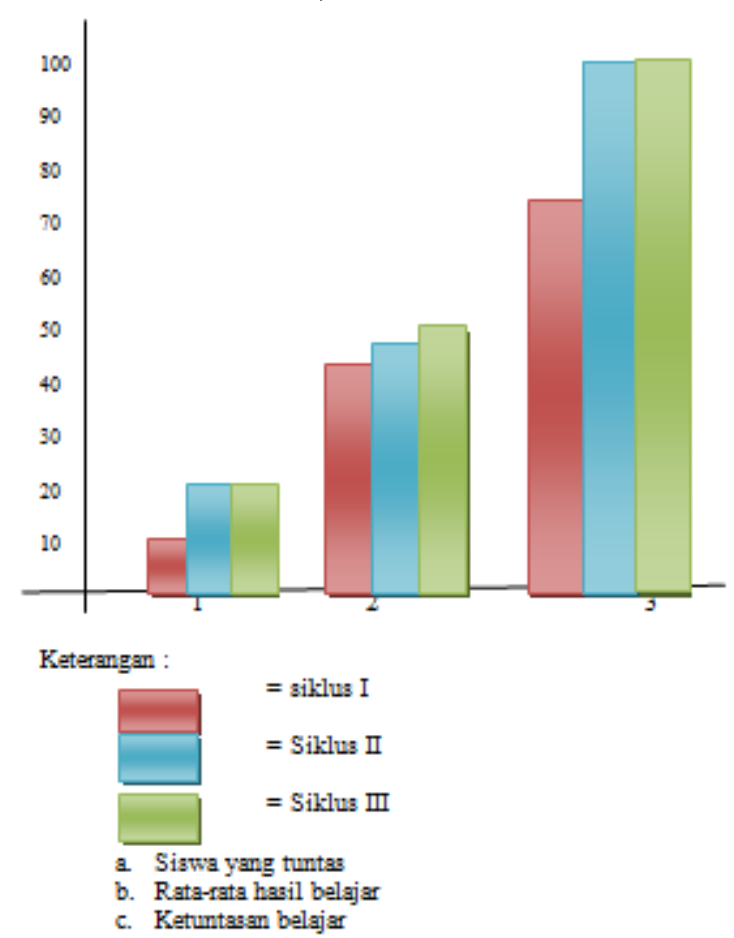

\section{TEMUAN DAN DISKUSI}

Model pembelajaran merupakan salah satu strategi pembelajaran yang diperlukan untuk mengetahui target pencapain hasil belajar siswa yang terbukti pada siklus I $76,19 \%$, siklus II $100 \%$, siklus III $100 \%$, maka dari itu guru sebagai pelaksana pembelajaran diharapkan dapat mengembangkan model pembelajaran sehingga pemahaman siswa terhadap suatu konsep mata pelajaran menjadi relatif lebih baik, untuk menerapkan sebuah metode pelajaran kooperatif tipe group to group diperlukan saran dan prasaran yang dapat menungjang terjadinya proses pembelajaran yang diinginkan, oleh karena itu didalam menerapkan metode kooperatif tipe group to group diperlukan adanya berbagai intrumen yang dapat menunjang dan memperlancar proses pembelajaran, sehingga nantinya memper-mudah siswa untuk memahami konsep dan tujuan yang hendak dicapai didalam proses belajar tersebut.

Saran dan prasaran yang pertama yang perlu dipersiapkan oleh guru adalah modul dan metode pembelajaran. Modul belajar adalah hal yang sangat penting dalam hal menungjang proses pembelajaran karena dalam modul ini selain membahas tentang materi pembelajaran juga dalam penyusunannya memberikan pengantar dan arahan bagi siswa agar dapat melakukan pembelajaran dengan baik dan benar.

Hasil observasi aktivitas belajar siswa pada mata pelajaran PKn menggunakan metode kooperatif tipe group to group pada siklus I yaitu tergolong dalam kreteria sedang 2,79 ini dikarenakan oleh beberapa faktor yaitu guru tidak melakukan apersepsi sebelum pelajaran dimulai, guru kurang memberikan motivasi dengan tidak menyampaikan tujuan dan manfaat dari pelajaran yang sedang berlangsung, guru tidak menfasilitasi siswa untuk berkreasi sesuai dengan bakat dan kemampuannya.

Dengan demikian kekekurangan pada siklus II, maka guru berusaha melakukan perbaikan-perbaikan pada hal-hal yang masih kurang pada pelaksanaan tindakan pada siklus I. Dengan melakukan perbaikanperbaikan yang dianggap kurang pada pelaksanaan siklus sebelumnya sehingga pada siklus II terlihat terjadi peningkatan. Dengan perbaikan-perbaikan kembali pada siklus-siklus sebelumnya sehingga pada siklus III terjadi peningkatan yang memuaskan.

Tercapainya aktivitas ini karena dalam setiap proses pembelajaran siswa diberikan motivasi untuk belajar terus, serta terlibat secara aktif dalam kegiatan belajar mengajar. Hasil tes siklus III yang menunjukan kriteria tinggi karena terjadinya peningkatan pada setiap aspek dalam diskusi kelompok. Kondisi tersebut sesuai dengan pendapat [17] bahwa tehnik-tehnik pembelajaran diskusi kelompok lebih unggul dalam meningkatkan aktivitas dan prestasi belajar siswa karena siswa lebih memiliki kemungkinan menggunakan tingkat berpikir yang lebih tinggi selama dan setelah diskusi dalam kelompok dari pada mereka bekerja secara individual atau kompetitif.

Dengan memperhatikan proses pembelajaran dalam hasil observasi yang diperoleh, diketahui, bahwa pembelajaran dengan penugasan terstruktur melelui metode pembelajaran kooperatif tipe group to group.

\section{E. SIMPULAN DAN SARAN}

Hasil penelitian menunjukkan bahwa pembelajaran dengan menggunakan metode kooperatif tipe group to group pada pembelajaran $\mathrm{PKn}$ dapat meningkatkan aktivitas belajar siswa kelas VII , karena aktivitas belajar siswa dari silkus ke siklus mengalami peningkatan aktivitas belajar, terlihat dari antusias siswa dalam mengikuti pembelajaran siswa menjadi lebih aktif dan terjadi saling ketergantungan yang positif diantara siswa, sehingga hasil penelitian ini terdapat hubungan yang signifikan antara penerapan pembelajaran kooperatif tipe group to group dengan meningkatkan hasil belajar siswa mata pelajaran PKn kelas VII di MTs. Al-Intishor Tanjung Karang Mataram.

Sementara saran ditujukan kepada guru diharapkan kepada guru PKn di MTs. Al-Intishor Tanjung Karang 
Mataram agar mempertimbangkan taraf berpikir anak sebagai acuan dalam memilih metode dan strategi belajar. Sekolah hendaknya selalu mendorong guru-guru untuk menerapkan model maupun metode yang menerapkan siswa sebagai subjek belajar bukan sebagai obyek belajar, disamping itu juga dapat dijadikan acuan untuk meningkatkan pembelajaran dikelas sehingga hasil belajar siswa pada mata pelajaran PKn maupun mata pelajaran yang lainnya akan semakin meningkat.

\section{UCAPAN TERIMA KASIH}

Penulis mengucapkan terima kasih kepada semua pihak yang terlibat yang senantiasa memberikan dukungan dana kegiatan maupun data penelitian kepada penulis sehingga artikel ilimiah ini selesai dengan baik.

\section{DAFTAR RUJUKAN}

[1] R. Indonesia, "Undang-undang Nomor 20 tahun 2003 tentang Sistem pendidikan nasional," 20AD.

[2] M. Mustari and M. T. Rahman, "Manajemen Pendidikan.” RajaGrafika Persada, 2014.

[3] D. P. Nasional, "Materi Pelatihan Terintegrasi Mata Pelajaran Sains." Jakarta: Bagian Proyek Pengembangan Sistem dan Pengendalian Program, 2004.

[4] A. Suharsimi, "Prosedur Penelitian, Jakarta: PT," Rineka Cipta, 2013.

[5] M. B. A. Riduwan, "Skala Pengukuran Variabelvariabel Penelitian," Alf. Bandung, 2007.

[6] H. Jauhari, "Panduan Penulisan Skripsi Teori dan Aplikasi," Bandung: Pustaka Setia, 2010.

[7] A. Sudijono, "Pengantar Evaluasi Pendidikan," Jakarta Raja Graf. Persada, 2006.

[8] S. Arikunto, Prosedur Penelitian Suatu Pendekatan Praktik. 2006.

[9] W. Surakhmad, Pendidikan Nasional, Strategi, dan Tragedi. Penerbit Buku Kompas, 2009.

[10] S. Margono, "Metodologi Penelitian Pendidikan." Jakarta: Rineka Cipta, 2005.

[11] S. Arikunto, "Prosedur Penelitian; Suatu Pendekatan Praktek Jilid 2," PT Rhineka Cipta Jakarta, 2004.

[12] M. Nazir, "Metode Penelitian, Cet. 10," Bogor Penerbit Ghalia Indones., 2014.

[13] W. Rochiati, "Metode Penelitian Tindakan Kelas," Bandung PT Remaja Rosdakarya, 2005.

[14] L. J. Moleong, Metode Penelitian Kualitatif. Bandung: Remaja Rosdakarya, 2007.

[15] A. Raksun, "Implementasi Pembelajaran Kooperatifuntuk Meningkatkan Motivasi Dan Hasil Belajar Mahasiswa Program Studi Pendidikan Fisika FKIP Universitas Mataram PadaMata Kuliah Biologi Dasar," J. pijar MIPA, vol. 4, no. 1, 2009.

[16] M. N. Purwanto, Prinsip-prinsip dan Teknik Evaluasi Pengajaran. Remaja Rosdakarya, 2000.

[17] M. Ibrahim, "Pembelajaran Kooperatif." Surabaya: University Press, 2000. 